\section{THE ROLE OF THAI}

\section{ARCHITECTS IN URBAN HOUSING DEVELOPMENT}

\section{Bundit Chulasai $^{1}$}

\section{Introduction}

It is understandable that housing in Thailand, especially in urban areas, has been rapidly developed during the last twenty years, due to national, economic and socio-cultural change. Housing has evolved from a simple shelter, built by an occupant, to a real estate project, involving several professional participants. For a long time in the past, a house was considered a work of folk art, and housebuilding was a part of local knowledge. But at the present time, housing in considered a consumer product, housebuilding is the province of the real estate business.

Due to economic growth (Table 1) and the increasing activities in industry and the service sector, there is a larger number of people who earn more and regular income. These people can afford to either purchase or rent housing from the real estate market. As a result, housing problems in the Bangkok Metropolitan Region (BMR), which covers Bangkok and the vicinity provinces such as Nakornprathom, Nonthaburi, Prathumthani, Samuthprakarn and Samuthsakorn, have been ameliorated.

${ }^{1}$ Associate Professor, Department of Architecture,Faculty of Architecture, Chulalongkorn University, Thailand.
Along with this rapid change in housing development, the role of architects has had to be modified. This paper aims at explaining how urban housing in Thailand has changed and suggesting what roles Thai architects should play today.

\section{Housing Production}

It is rare for any ocupant to gather his friends and build his own house, either in an urban or a rural area. It seems to be very difficult for anyone to build his own house because of the complexity of the process, which starts from having a piece of land, commissioning an architect to design the house, hiring a contractor and craftsmen or laborers to build it, and obtaining a loan from a financial institution. Therefore, people prefer to look for a house developed by government or private agencies.

Figure I shows that there are many participants involved in housing production. They are :

A - Architects/designers who are responsible for both function and aesthetics,

B - Builders, including contractors, all kinds of technicians and laborers, who realize the house,

D - Developers--a small real estate 
Table 1 Summary of Population \& Economics of Thailand

\begin{tabular}{|c|c|c|c|c|c|}
\hline & 1990 & 1991 & 1992 & 1993 & 1994 \\
\hline TOTAL POPULATION (million) & 56.30 & $\begin{array}{l}56.96 \\
(1.17)\end{array}$ & $\begin{array}{l}57.79 \\
(1.46)\end{array}$ & $\begin{array}{l}58.34 \\
(0.95)\end{array}$ & $\begin{array}{l}59.02 \\
(1.17)\end{array}$ \\
\hline URBAN POPULATION (million) & 9.94 & $\begin{array}{l}10.04 \\
(1.01)\end{array}$ & $\begin{array}{l}10.23 \\
(1.89)\end{array}$ & $\begin{array}{l}10.24 \\
(0.10)\end{array}$ & $\begin{array}{l}10.34 \\
(0.98)\end{array}$ \\
\hline $\begin{array}{l}\text { URBAN POPULATION BANGKOK } \\
\text { METROPOLITAN REGION BMR. }\end{array}$ & 8.54 & $\begin{array}{l}8.70 \\
(1.87)\end{array}$ & $\begin{array}{l}8.66 \\
(0.46)\end{array}$ & $\begin{array}{l}8.77 \\
(1.27)\end{array}$ & $\begin{array}{l}8.85 \\
(0.91)\end{array}$ \\
\hline $\begin{array}{l}\text { GROSS DOMESTIC PRODUCT } \\
\text { GDP (billion baht) }\end{array}$ & $2,191.00$ & $\begin{array}{l}2,506.00 \\
(14.38)\end{array}$ & $\begin{array}{l}2,805.00 \\
(11.93)\end{array}$ & $\begin{array}{r}3,124.00 \\
(11.37)\end{array}$ & $\begin{array}{r}3,542.00 \\
(13.83)\end{array}$ \\
\hline PER CAPITA GNP (baht) & $39,055.00$ & $\begin{array}{r}44,042.00 \\
(12.77)\end{array}$ & $\begin{array}{c}48,529.00 \\
(10.19)\end{array}$ & $\begin{array}{c}53,317.00 \\
(9.87)\end{array}$ & $\begin{array}{c}59,624.00 \\
(11.83)\end{array}$ \\
\hline ECONOMIC GROWTH RATES (\%) & 11.60 & 8.40 & 7.90 & 8.20 & 8.50 \\
\hline $\begin{array}{l}\text { EXPANSION OF INVESTMENT } \\
\text { IN PRIVATE SECTOR (\%) }\end{array}$ & 23.50 & 12.20 & 5.00 & 13.20 & 11.40 \\
\hline INFLATION RATES & 6.00 & 5.70 & 4.10 & 3.30 & 5.00 \\
\hline
\end{tabular}

FIGURE I "TO BUILD A HOUSE"

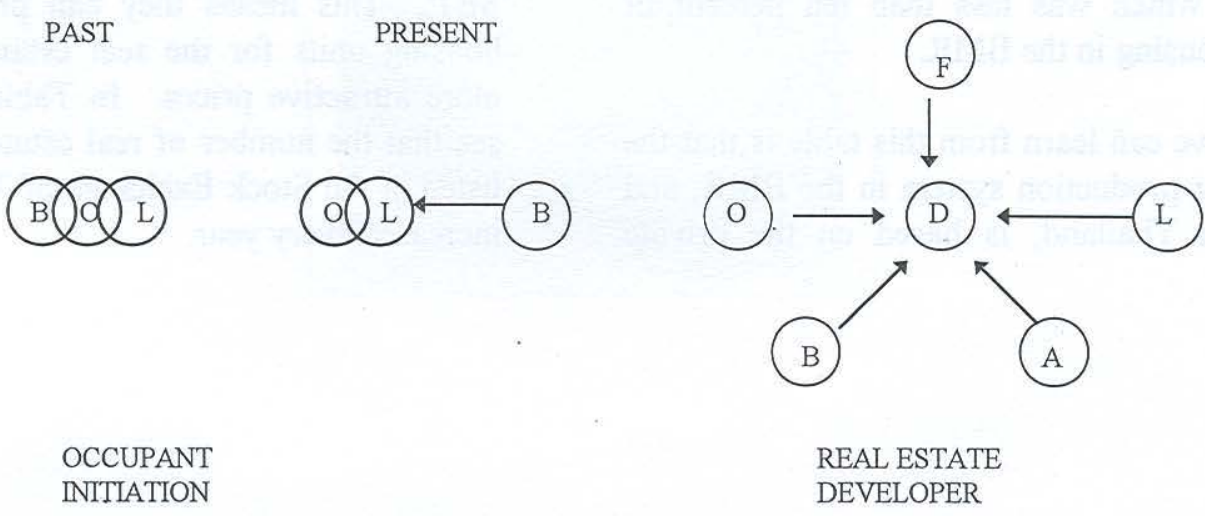


company, a large enterprise or the National Housing Authority (NHA) who plan and implement public housing projects,

F - Financial Institutions--including savings banks, housing banks, private banks, financial companies both local and foreign, and the Stock Exchange of Thailand SET,

L - Landlords, who own the property,

O - Occupants, who either rent or purchase the housing unit.

Table 2 shows the number of housing units produced by different initiations, which are: Occupant initiation, Real estate developer, NHA, Housing in slum area and etc. In 1991, there were over two million housing units for a population of 8.7 million, or about 4 inhabitants per unit. The total number of housing units of all types increased four-fold between 1987 and 1991. During the same time, the number of housing units, built by a real estate developer increased ten times.

Therefore, in 1991, the number of housing units built by real estate developers was more than half of the total number of housing units in the BMR, and twice as many as the number of units built by occupant initiation. The number of NHA-built housing units was similar to the number of houses built in slum areas, which was less than ten percent of total housing in the BMR.

What we can learn from this table is that the housing production system in the BMR, and also in Thailand, is based on the private sector. Public housing, in fact, is not an important housing supplier for Thai people.

After years of establishment, the NHA, the sole public housing agency, in a country of sixty million people, can produce less than 20,000 units per year. As a result, low income earners build their own shelters in far suburban areas, or more commonly in slum areas near the city center, while the higher income earners build or shop from the housing market.

For this reason, the government recently decided to encourage the private sector to produce more low income housing. Starting in 1992, the National Board of Investment (BOI) began granting tax privileges to low cost housing projects. The number of new low cost housing units has, consequently, increased five times. In 1994, BOI housing projects successfully supplied 130,000 units, which is ten times, the number supplied by the NHA. (See also Table 3)

Apart from BOI low cost housing projects, the private sector also has greater access to financial institutions. For example, a large real estate developer can become a public company listed in the Stock Exchange of Thailand (SET). In 1994, about thirty public companies increased the possibility of financing their housing projects through the SET. This mearis they can produce more housing units for the real estate market at more attractive prices. In Table 4, we can see that the number of real estate companies listed in the Stock Exchange of Thailand has increased every year. 
Table 2 Number of Housing in BMR.

\begin{tabular}{lcccc} 
& 1988 & 1989 & 1990 & 1991 \\
\hline Occupant initiation & 341,732 & 470,386 & 519,380 & 555,839 \\
Real Estate Developer & 361,308 & 851,966 & $1,104,664$ & $1,202,291$ \\
NHA & 91,349 & 131,150 & 141,192 & 168,351 \\
Slum & 160,145 & 191,000 & 183,548 & 182,457 \\
etc & 60,543 & 40,000 & 40,000 & 40,000 \\
\hline Total & $1,015,077$ & $1,684,502$ & $1,988,784$ & $2,148,938$ \\
\hline
\end{tabular}

Table 3 New Low Cost Housing in Thailand

\begin{tabular}{lcrrc} 
& 1991 & 1992 & 1993 & 1994 \\
\hline BOI Project & - & - & 1,796 & 130,735 \\
NHA Project & 1,004 & 9,038 & 20,080 & 9,709 \\
NHA Slum Upgraded Project & 9,057 & 7,755 & 4,156 & 4,986 \\
\hline Total & 10,061 & 16,793 & 26,032 & 145,430 \\
\hline
\end{tabular}

Table 4 Real Estate Public Company

\begin{tabular}{ccc}
\hline Year & Total number & $\%$ of Charge \\
\hline 1990 & 6 & \\
1991 & 13 & $116 \%$ \\
1992 & 17 & $30 \%$ \\
1993 & 26 & $52 \%$ \\
1994 & 32 & $23 \%$ \\
\hline
\end{tabular}




\section{Housing Types in the BMR}

As the system of housing production varies from a single unit of occupant initiation to a hundred thousand units initiated by a publicly-owned real estate company - the Muengthong Thani Project of Bangkok Land for instance, envisions a new town north of the BMR with a population of 200,000 - and since housing in the BMR has developed over a long time, many housing types have also been created. They can be categorized by the system of production, the morphology, the occupant, etc. Figure II shows different types of housing categorized by the occupant's income and the project initiator.

However, as mentioned before, the majority of housing in the BMR is produced by private development. Houses, initiated by occupants, are generally, detached houses, built on their own property. Real estate developers supply detached, and semidetached houses, a rowhouses (also called shophouses), for both commercial and residential use, and townhouses for residential use only, at varying distances from the city center, and condominiums-multi-family housing where many occupants own their single housing unit within the same building but share some common facilities .

Table 5, shows the number of new housing units built each year between during 19911994. The data is categorized by initiator (either occupant or real estate company) and housing type: detached, rowhouse, or condominium. Since most of the houses built by an occupant are detached houses, the number of detached houses and rowhouses from both initiations exceeds the number of condominiums. This is simply because people prefer them for their better environment and for their similarity to a traditional house.

However, the number of condominiums increased every year. If we look at the percentage of housing types built by real estate developers during the same period, (Table 6) condominiums account for almost half of the new housing units built every year. This multi-family housing, has in fact, gained recogrition in just the past fifteen years. But people prefer it for the price listed, the facilities provided, and its modern image. As a result, the number of condominiums has increased rapidly in urban areas around Thailand.

\section{The role of the architect}

The summary of facts and figures mentioned previously can partly explain the recent situation of housing in the BMR. Visitors can notice that the capital of Thailand has changed tremendously since the last decade. .In both contexts of housing production and housing type, the architect plays an important role in housing development, specifically, the transformation of housing

When housing production becomes a professional system, most of the housing built in the BMR requires the services of an architect. Larger projects and higher buildings, need more specialists, not only for the construction permit required by law, but also for their knowledge of both function and aesthetics. Architects play the role of 
FIGURE II Housing types in Bangkok

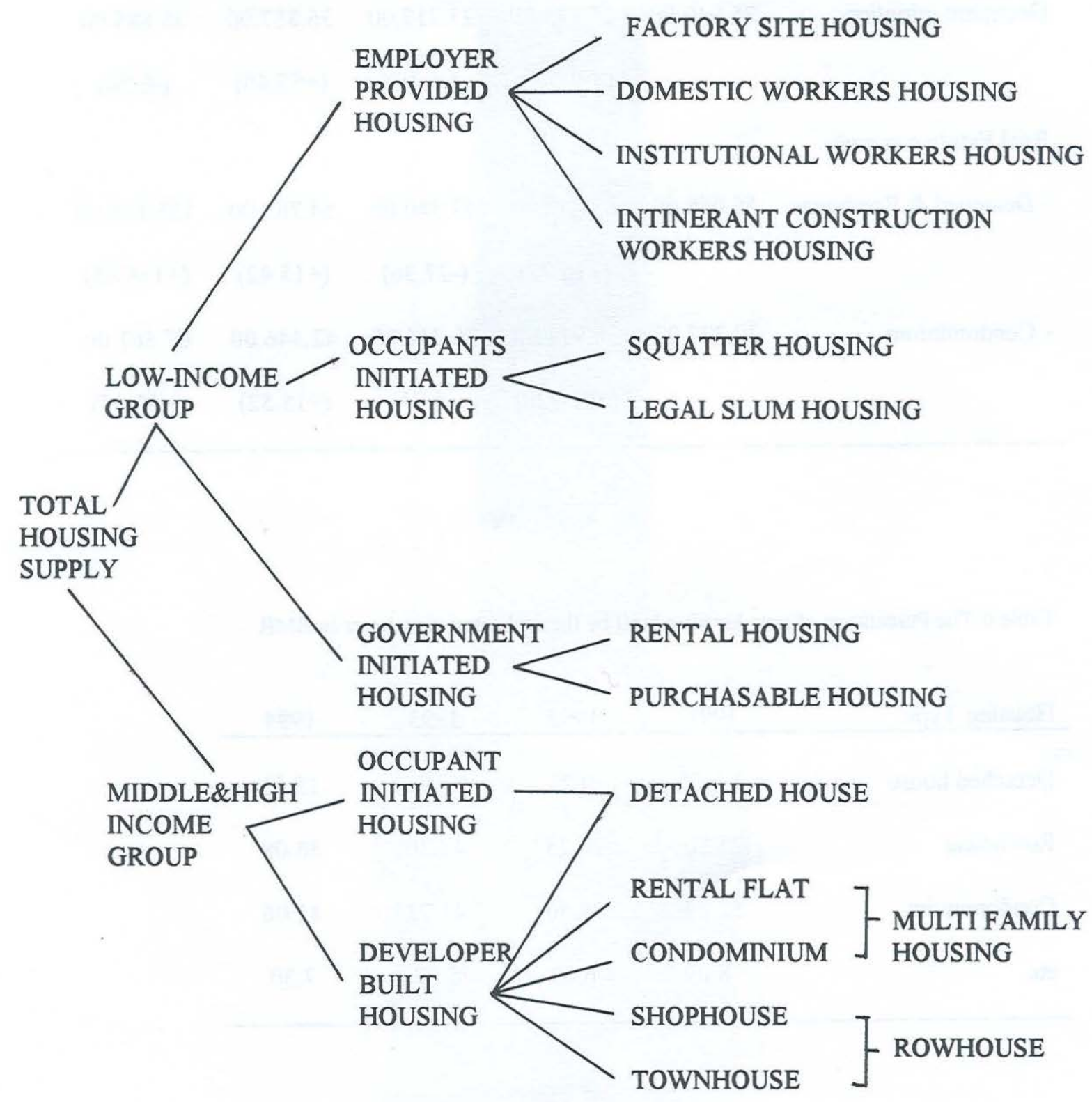

DERIVED FROM CHULASAI, B., 1983. 
MANUSYA: Journal of Humanities Vol. 1 No. 11998

Table 5 New Housing Production \& Type in BMR

\begin{tabular}{lccccc} 
& 1990 & 1991 & 1992 & 1993 & 1994 \\
\hline Occupant initiation & $25,940.00$ & $25,275.00$ & $23,717.00$ & $36,857.00$ & $35,885.00$ \\
& & $(-2.56)$ & $(-6.16)$ & $(+55.40)$ & $(-6.24)$ \\
Real Estate company & & & & & \\
- Detached \& Rowhouse & $56,068.00$ & $65,442.00$ & 47.540 .00 & 54.783 .00 & $135,125.00$ \\
& & $(+16.72)$ & $(-27.36)$ & $(+15.42)$ & $(+146.65)$ \\
& & $38,971.00$ & 36.744 .00 & 42.446 .00 & 67.561 .00 \\
- Condominium & $20,327.00$ & $360)$ & $(-5.71)$ & $(+15.52)$ & $(+59.17)$ \\
\hline
\end{tabular}

Table 6 The Percentage of new housing built by the real estate developer in BMR

\begin{tabular}{lcccc} 
Housing Type & 1991 & 1992 & 1993 & 1994 \\
\hline Detached house & 13.72 & 9.23 & 9.90 & 15.56 \\
Rowhouse & 25.30 & 26.25 & 43.30 & 36.08 \\
Condominuim & 52.89 & 58.50 & 41.73 & 41.06 \\
etc & 8.09 & 6.02 & 5.07 & 7.30 \\
\hline
\end{tabular}


intermediary between the owner and the builder for houses initiated by the occupant, and between the developer and the contractor for those initiated by a real estate developer.

In many cases, the architect also plays the combined role of designer and contractor and in some cases developer also, depending on his/her experience. Some architects are now the key persons in private and publicly owned real estate companies. Therefore, the Department of Housing Development, the only formal educational institution of its kind, was established in the Faculty of Architecture, Chulalongkorn University, a few years ago.

In terms of housing morphology, production ranges from traditional Thai houses to any style of compound house according to the architect's and the owner's taste. Those include: bungalow, Victorian and Missionary styles of the past, Californian, modern and post-modern styles of the present time, as well as Mediterranean, Spanish and French villas, Swiss and Bavarian chalets and Neoclassic style. They can be seen in many part of the city. A reason for this phenomenon is that housing has become a consumer product which needs to be segmented to suit different markets.

On the other hand, the architect also improves the design of a rowhouse, either to be used as a shophouse or as a townhouse, by creating different interior space and facade. Therefore, rowhouses have become popular among clients who prefer a detached house or who want to live near the city center but have a limited budget.
Condominiums represent a totally new environment, in comparison with a Thai house on stilts in the former time. The architect, therefore, has to facilitate condominium owners in many ways, such as providing a luxury environment for high income occupants. In contrast, the architect has to cut construction costs for lower income condominiums.

As the housing morphology changes from a one or two-storey building to a row of three or four-storey buiding or to a large, high building, the architect, again, has to introduce different techniques of construction and building material. To offer housing units at competitive prices, the architect has to search for an appropriate design. Lower construction costs can come from the suitable material, minimal use of material and labor. The prefabricated system can cut construction costs and time, compared with the conventional system. When housing becomes a high rise building such as a condominium, the price of a housing unit is, directly, cut in terms of the land cost compared with that of a detached or row house.

Improvements in the production system and building types in housing development, have incrcased the quantity and quality of housing in the BMR. The problem of housing demand and squatter housing has decreased due to this change. Low cost condominiums in suburban areas are now available for low income earners. Moreover, when there is an over-supply of low-cost housing units, the developer can turn them into rental apartments, not only for low-low income 
earners but also for young couples, factory or service workers, students etc. Rental rooms in many slum areas, which were once needed by this population, are now less numerous.

The problem of land use and traffic in the BMR has also been partly solved by the development of multi-family housing. High and middle income earners, who prefer to spend less time traveling to and from work, turn to the condominium in the city center or near the sub-center. As a consequence, the housing density in these areas has increased. Therefore, the problem of urban sprawl and commuting traffic has also partly declined.

As the quantity of housing units has increased, the quality of housing has also ameliorated. Architects provide better living units in condominiums with many common facilities such as a car park, swimming pool etc., as well as many utilities, such as a water treatment system, fire protection, etc. For detached house and rowhouse projects in suburban areas, architects provide small open spaces, clubhouses and other facilitites and utilities.

\section{Conclusion}

Even though housing problems in the BMR have eased because of many policies and solutions, the architect continues to play an important role in housing development and improvement. But there are still other housing problems such as community environment and facilities, building safety in low-income condominiums, the need for construction worker housing, the assessment of the impact of housing projects on the environment, the better quality of open space for housing residents, and the study of human behavior on housing environments. Thai architects have a responsibility to create a built environment which harmonizes with the natural environment, to search for appropriate technologies, to save energy and natural resources, and to maintain the national identity in the face of globalization.

\section{References}

Chulasai B., L'Evolution des lodgements urbains a Bangkok, Thailand. These de III cycle, Unite Pedogogique d' Architecture No.1, Paris, 1983

Housing in Thailand 1994, Annual Report of The National Housing Board, published by Housing Bank, 1995.

Note

All the tables are derived from Housing in Thailand 1994. 